\title{
Lesão pulmonar exuberante
}

\section{Exuberant lung injury}

Homem com 46 anos, residente em meio rural e trabalhador da construção civil, foi referenciado por uma lesão descrita como quística no campo pulmonar direito (Figura 1 e 2). Como antecedentes destacase 0 consumo excessivo de álcool e tabaco. 0 doente referia tosse produtiva com dois meses de evolução, esporadicamente hemoptóica e toracalgia posterior. Negava dispneia, sintomas constitucionais ou quaisquer outras queixas. Apresentava-se emagrecido, eupneico e com murmúrio vesicular mantido bilateralmente. Realizou estudo tomográfico que revelou uma volumosa lesão expansiva no lobo inferior direito, com $14.1 \times 12.9 \mathrm{~cm}$, maioritariamente líquida e com algumas bolhas gasosas no seu interior, envolvendo o brônquio lobar inferior direito, obstruindo-0 quase completamente (Figura 3). Optou-se pela remoção cirúrgica da massa, que macroscopicamente apresentava 950g (Figura 4), com 13 cm de maior eixo e cujo relatório microscópico revelou tratar-se um carcinoma epidermóide, variante papilar.

0 carcinoma do pulmão representa um problema de saúde pública, sendo a neoplasia responsável pelo maior número de mortes a nível mundial. Felizmente, com a diminuição do consumo de tabaco a incidência deste tipo de tumor tem vindo a decrescer, embora a população que ex-fumadora se mantenha em risco1,2. 0 carcinoma epidermóide, muito associado ao tabagismo, geralmente apresenta uma localização central e é o que mais frequentemente é diagnosticado com exames radiológicos inocentes3,4. 0 tumor de células grandes, pelo contrário, geralmente manifesta-se como uma massa periférica de grande tamanho e seria este o que esperávamos encontrar. No caso apresentado a lesão era exuberante, embora não se traduzisse ao exame físico pela sua localização anterior, poupando o lobo inferior direito. Pelo contorno tão regulares e conteúdo liquido, colocamos ainda a hipótese de se tratar de hidatidose de localização pulmonar.

0 doente iniciou posteriormente quimioterapia e radioterapia adjuvantes, apresentando aos 12 meses, uma evolução pouco favorável, vindo a apresentar doença óssea metastática, aos 4 meses após diagnóstico.

\section{Bibliografía}

1. Field JK, Duffy SW. Lung cancer screening: the way forward. British Journal of Cancer. 2008; 99: $557-62$

2. De la Cruz, CS, Tanoue LT, Matthay RA. Lung Cancer: Epidemiology, Etiology, and Prevention. Clin Chest Med. 2011; 32(4): 605-44.

3. Rosado-de-Christenson ML, Templeton PA, Moran CA. Bronchogenic carcinoma: radiologicpathologic correlation. Radiographics. 1994;14(2):429-46; quiz 447-8.

4. Munden RF, Swisher SS, Stevens CW, Stewart DJ. Imaging of the Patient with Non-Small Cell Lung Cancer. Radiology; 2005; 237: 803-818.

\section{Diagnóstico: Carcinoma Epidermóide do Pulmão Exuberante}

\section{Catarina Canha, Elisa Meira}

Serviço de Medicina Interna, Hospitais da Universidade de Coimbra, Centro Hospitalar e Universitário de Coimbra. Portugal

Correspondencia: catarina.canha@gmail.com

Como citar este artículo: Canha C, Meira E

Carcinoma Epidermóide do Pulmão Exuberante. Galicia Clin 2014; 75 (1): 46

Recibido:16/10/2013; Aceptado: 9/1/2014
Figura 1. Radiografia do tórax, póstero-anterior.

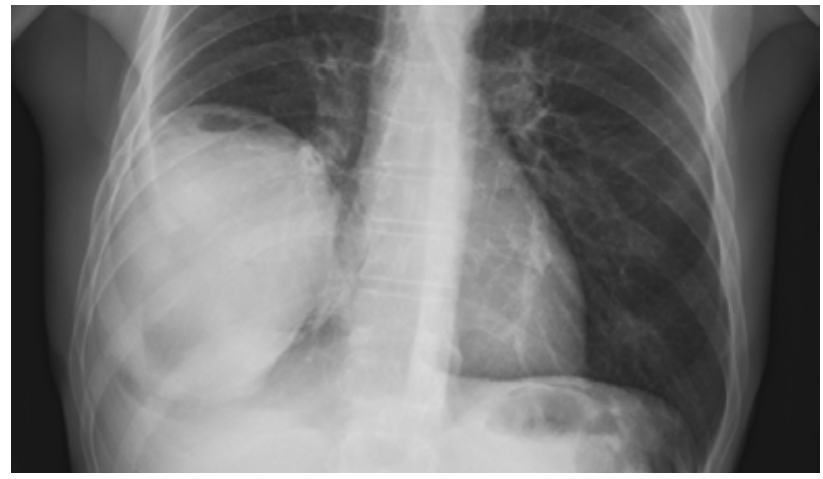

Figura 2. Radiografia do tórax, lateral.

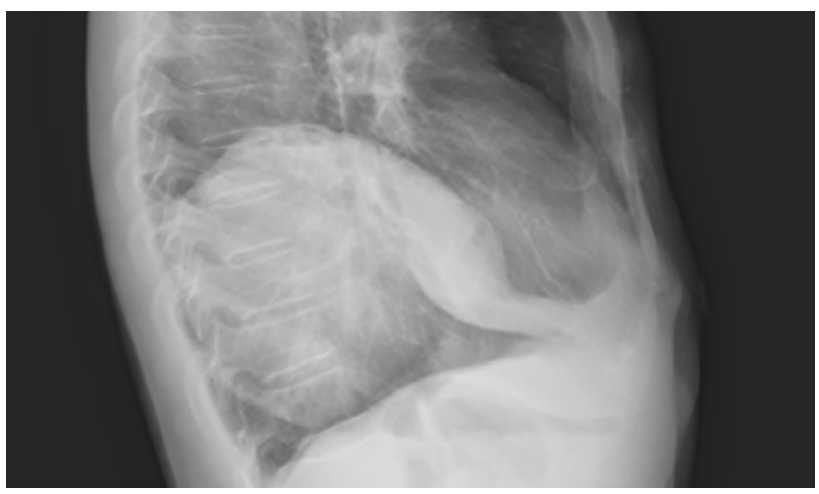

Figura 3. Aspecto da lesão em tomografia computorizada.

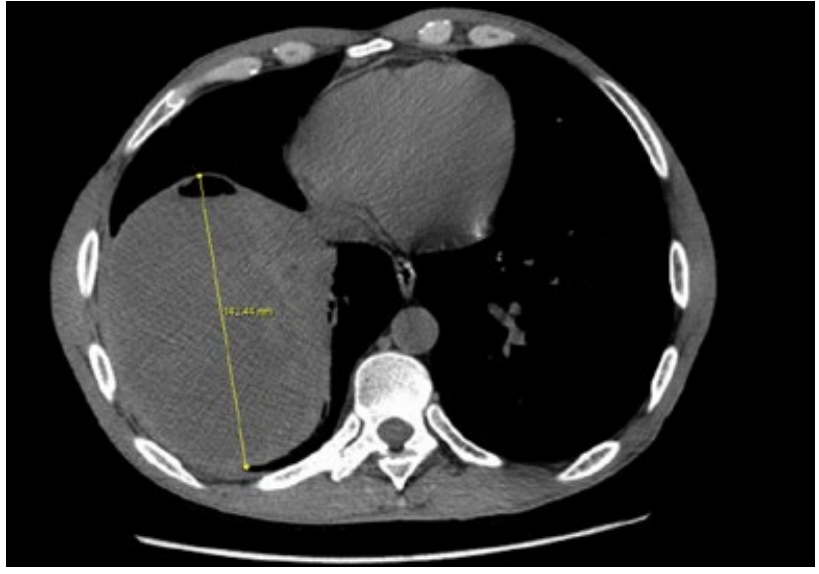

Figura 4. Aspecto macroscópico da massa excisada.

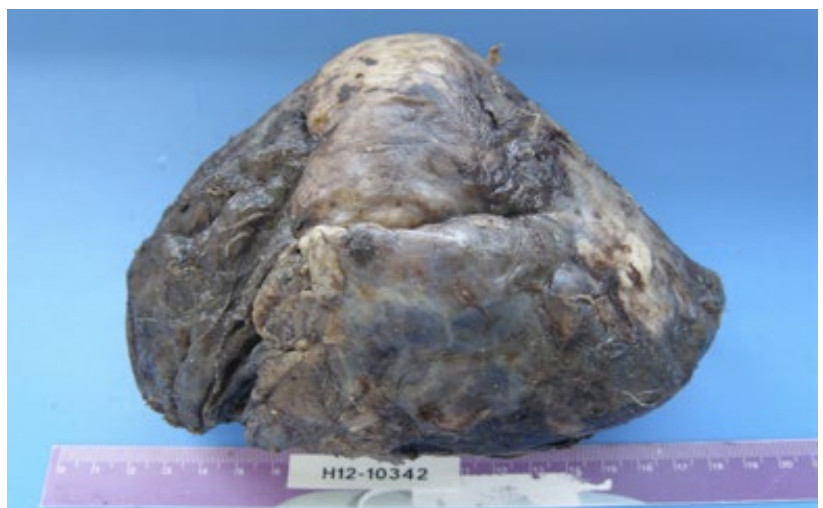

